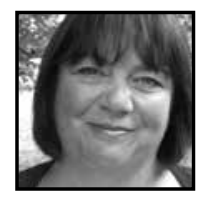

\title{
Opening Up to Student Voice: Supporting Teacher Learning Through Collaborative Action Research
}

\author{
Emily Nelson, Eastern Institute of Technology, New Zealand
}

\begin{abstract}
Student voice is promoted increasingly as a vehicle to enhance student learning and improve schools. Whilst the need for amplifying neglected student perspectives in learning and improvement processes is well established, supporting teachers to learn from students has received less attention. The author argues that collaborative action research supports teachers to engage with their students as decision-making partners in the classroom and to learn from them about effective pedagogy at the same time. The approach provides reflective spaces for teachers to notice and challenge takenfor-granted roles and practices, and to address expectations on their work sometimes contradictory to their student voice goals.
\end{abstract}

\section{Introduction and Background to the Research}

am committed to student voice as socially just action. I believe students bring a unique, valuable, and often missing perspective to the educational equation and should be supported by educators to form and share these perspectives. However, a pervasive view of children and young people as immature and unable to articulate and advocate for their own interests perpetuated their traditional exclusion from educational debate, design, and decision-making until recent challenges to this view gained purchase.

Increasingly, the need to include students is advocated, even at official levels, but the implications for teachers and the role they need to play in according students 
more influence receives less attention. In this paper I explore how a collaborative action research, approach supported three teachers to learn with, and from, their students as partners in order to co-construct effective pedagogy. The three teachers who participated in this research were also motivated by this challenge. Initially, we posed the question, "How do young adolescent students perceive effective teaching in relation to their needs and aspirations as learners?" If we had stopped there the research would have elicited the views of students, but left them largely passive, excluded from the decisions and actions that followed their consultation. However, with our shared commitment to engaging students as partners, the research challenge expanded. Through collaborative action research we explored how the teachers might utilize their students' perceptions of effective teaching and engagement in order to co-construct effective pedagogy with them. It is this question, and the challenges and insights it generated for teacher research, that focus this paper.

\section{Student Voice Practices and Agendas}

"Student voice" is a term used to describe the project of increasing the status of students and addressing their traditional exclusion from educational debate, design and decision-making (Fielding, 2004). With the advent of the new sociology of childhood (James \& Prout, 1990), children and young people are increasingly viewed as active meaning makers, capable of acting in their own interests and contributing unique and valuable perspectives on their experiences as young people, and by extension, students.

Student voice is enacted through research and pedagogical practice in schools. From its democratic and progressive beginnings contemporary student voice practice now serves agendas related to school improvement, enhancing learning, student engagement, consumer rights, and social justice. A proliferation of different practices has emerged with this expansion of the student voice agenda, but not all of these practices improve students' status and influence. To avoid reductive practices that leave students consulted yet passively positioned, active student participation has emerged as an important criterion of student voice (Rudduck, 2007). In an action-orientation, student voice is conceptualized as ongoing dialogue and interaction between students and teachers on decisions and issues important to both-a joint enterprise (Lodge, 2005; Mitra, 2008). Lundy (2007) argues that student voice research that promotes influential student participation must include four essential and interrelated elements: (1) space, for the expression of students' views; (2) voice, including adult support to assist young people to actively construct and express a viewpoint; (3) an audience for students' views; and the most difficult to achieve (4) influence, explicit evidence that students' views do influence teachers' thinking and the action that follows student consultation. 
Elevating students' status involves changing existing power relations, primarily the power differential between students and teachers. As the "gatekeepers of change" (Rudduck, 2007) in schools and in classrooms, in order for student voice to flourish in classrooms teachers must authorize listening to students as legitimate and valuable to the learning process and to their work (Cook-Sather, 2002). Locating student voice research in the classroom can maximize the influence of students on teachers' thinking (Flutter, 2007; Lincoln, 1995; Smyth, 2006) as classrooms represent the key site of professional energy for teachers (Cox \& Robinson-Pant, 2008). However, despite increased classroom-based student voice projects, student involvement in pedagogical decisions remains rare (Thomson, 2011). Elevating students in the student/teacher relationship necessitates attending to teachers' voice, teachers as learners, and the realities that impact on teachers' work in classrooms (Fielding, 2001). In short, whatever form student voice takes, it will involve students and teachers engaging in new roles and practices with each other and involve significant learning for teachers (Mitra, 2006; Smyth, 2007).

\section{Supporting Teachers as Learners to Enact Student Voice}

Learning from students can be a reflexive process for teachers "with the learning of students ... functioning as a kind of reflecting pool or mirror" (Cochran-Smith, 2003, p. 19) that can transform pedagogy (Kane \& Maw, 2005), but only when teachers are supported to hear and take account of the messages students communicate (Bragg, 2001). Learning can involve "unlearning some long-held ideas, beliefs, and practices, which are often difficult to uproot" (Cochran-Smith, 2003, p. 9). Learning opportunities are needed that link teachers' inquiries to their work and to valued student outcomes (Putnam \& Borko, 2000). These opportunities must also foster authentic relationships with researchers and colleagues to support risk-taking (Little, 2004). Teachers' work and learning are also nested within their larger school cultures and policy contexts. These contexts influence the possibilities teachers have available to elevate students' status and influence in practice. In promoting student voice, the limited autonomy teachers possess to act autonomously within the education systems in which they operate must be acknowledged (Taylor \& Robinson, 2009).

\section{Research Design}

I identified collaborative action research (CAR) as a potential approach to support teacher learning and promote student influence because of its central focus on improving and challenging practice "through dialogue and collaboration" (Locke, Alcorn, \& O'Neill, 2013, p. 112). CAR promotes the involvements of all significant actors relevant to an issue or area of focus, including students. Together CAR participants 
work in authentic ways to re-examine and propose new practice whilst taking account of factors within the broader social context that impact on action possibilities (Collins, 2004; Kemmis \& McTaggart, 1989). In this research CAR provided the vehicle for students and teachers to work together as partners to co-construct effective pedagogy. It also offered reflective processes to support and challenge teachers' learning in light of their new student voice goals and the broader demands on their practice.

The setting and participants. Three experienced teachers, Betty, Chicken, and Lincoln (pseudonyms) participated with their students in the research across three terms of a four-term school year. The teachers were members of the same learning team within one New Zealand Intermediate School (catering for students aged 11-13). Their 90 students participated in the classroom research activities primarily as their class curriculum but each was able to opt out of having their class work, perspectives, and images included as data in the research. A voluntary student research group (SRG) consisting of 12 students (four students from each of the three classes) participated as a focus group across the research.

The action cycles. The collaborative action research was conducted across three cycles. Action Cycle One (AC1) utilized visual methods to establish teacher and Student Research Group perspectives on effective pedagogy and conditions for engagement as the starting point for reflection, learning, and negotiated classroom action. The SRG completed a photo and drawing assignment in response to prompts around their perceptions of effective teaching, themselves as learners, conditions for engagement in learning at school, and their experiences of learning beyond school. SRG members led an exploration of their images with me in individual photo-elicitation interviews (Capello, 2005) that were audio-recorded and transcribed. The transcripts were returned to SRG members for member-checking (Mitchell, 1983) and analyzed by the three teachers. Emergent themes from this initial student voice data were explored by the teachers and their classes in Action Cycle Two (AC2) through discussion and visual mapping activities. In this way all 90 students collaboratively explored their perceptions of effective teaching and conditions for engagement with their teachers.

In Action Cycle Three (AC3) the students and teachers in each class co-constructed a class action research project. These projects aimed to better align one area of their class program with the student voice findings from $\mathrm{AC} 1$ and $\mathrm{AC} 2$. The teachers and their students adapted teaching strategies as data generation tools to plan, implement, and reflect on action as their class action research progressed. These strategies included questions, class discussions, minutes, class journals, individual student journals, video diaries, and charts. The teachers created video snapshots of classroom sessions 
periodically across AC3 to inform their reflection, planning, and collegial collaboration (Curry, 2012). Students who opted out of the research sat out of frame during these video snapshot recordings.

Regular collaborative teacher meetings held across the three action cycles provided opportunities for the teachers to analyze data, plan ongoing action, and reflect on their learning together. Individual teacher planning and reflection meetings, scheduled around the collaborative meetings, enabled each teacher to reflect on and plan their particular classroom action research projects with my input. Together we discussed ideas, planned for classroom action, and reflected on video snapshots of classroom practice. Regular focus group meetings with the SRG students enabled these students' reflections on aspects of the class action research projects to also inform their teachers' thinking, planning, and reflection. Their discussions with me were audio-recorded and the transcripts forwarded to their teachers (once their names were removed).

My role in the research. I participated in an insider/outsider researcher role in the research (Dwyer \& Buckle, 2009; Luke \& Gore, 1992). As an outside academic researcher I initiated the project and visited the school on scheduled occasions to conduct research activities with the teachers and SRG members. I also participated as a student voice "mentor" (Cowie et al., 2010), contributing my ongoing learning about student voice as a resource for teachers as well as my prior experience as a teacher and professional development facilitator. I reflected with the teachers on data, findings and significant challenges in the research, and made suggestions on how they might generate data with their students as partners. In this way I was fully implicated in the research and the findings that emerged.

\section{Collaborative action research-an opportunity for teachers' professional growth.} The research offered Betty, Chicken, and Lincoln an opportunity for professional growth relevant to their interest in student voice. The project also offered the teachers a way to understand their students more deeply and to respond to broader professional development messages around the necessity of student voice.

You hear all this, you know you go to [professional development] courses and stuff and it's all about student voice and you just think I'm sure I don't do enough of it and what does everyone else do and you know you sort of wonder if you do enough ... When you were sharing [the project] with the staff and you were talking about what kids think is good teaching, I started thinking that would actually be really interesting to know. And although as a teacher I think 'yep I could just ask kids' quite often you don't sort of get down into the nitty gritty of it. (Betty) 
From the teachers' perspective, working with students as partners positioned students to teach them how they could best be supported as learners.

I saw this as a chance for professional development for myself, to actually know what the kids wanted me to teach them. Like how I can be a more effective teacher? What my role is to help them become an effective learner? (Chicken)

The student voice focus also offered an opportunity for the teachers to "tap into" students' capacity to teach each other.

It's trying to try and have the students collaborating and working on things as well and identifying the strengths of a lot of students too ... so it's tapping into them and having the philosophy of students as teachers as well. (Lincoln)

Unlike traditional professional development where teachers learn from other educators, in this research the students provided the professional development, teaching their teachers, and each other, about effective teaching and conditions for engagement.

\section{Opening up to students as partners-teachers sharing their learning as a starting} point. The teachers shared their learning from Action Cycles One and Two with their classes as a starting point for the AC3 class action research projects. This dialogic move communicated to the students that their teachers had listened to their views on effective teaching and engagement, and were using this learning as a starting point for co-constructing more effective practice with them as partners. Each project also involved a personal learning challenge for each of the teachers, reflected in their research questions.

Betty's learning challenge was to make room for students to participate as pedagogical decision-makers to improve reflection practice in their class: "How can I include kids in designing self-assessment and reflection that is motivating and relevant to them?" At the outset of the project, the students wrote individual responses to prompts at the end of each week to reflect on their learning. Enthusiasm for this approach had waned with students and Betty viewing the practice as increasingly irrelevant. To re-vitalize flagging reflection practice in their classroom, Betty and the students collaborated to identify, implement, and evaluate the efficacy of a range of reflection strategies. They applied the "reflection trial" to their inquiry work and their class speech unit. 
Chicken's learning challenge was to let go the reins of overt teacher control to increasingly involve her students in pedagogical decisions.

I do want the student voice, I want them to have more power and I have got to make it work for me. I want them to be more child-initiated and directed projects, so they are involved in the decision making. (Chicken)

Together they explored the question, "What does effective home learning look like?" The students and Chicken had identified shortcomings with the current home learning-or homework-program. They decided the school-wide compulsory program did not provide sufficient opportunities for students' creative expression and imagination, nor were these tasks sufficiently relevant to students' own learning and their class curriculum. The students also perceived that home learning tasks were fragmented and they preferred tasks organized around a coherent theme.

Lincoln's ongoing professional learning challenge focused on how to build student leadership capacity and ownership of the class program: "How to [get] the students to take a little bit more ownership of what they were doing and how they could feed into what is happening in class so that it wasn't just teacher directed." He explored how to increase student ownership of the class inquiry by making a student-directed class movie. A student Production Team took decision-making control with Lincoln acting as a consultant to the Team when invited.

The three classes implemented their action research projects during class time and within their class program. This involved teachers and students negotiating, planning, and evaluating action together. Individual and collaborative teacher action research meetings in the teachers' non-contact time provided them space to reflect on and discuss their learning, as well as address implications in relation to the broader school and policy demands on their practice.

Opening up to students as partners-noticing, interrupting, and re-framing pedagogy. Opening up to students as partners required teachers' ongoing noticing, interrupting and re-framing their role in the student/teacher relationship and existing pedagogy in light of their student voice goals.

For Betty, opening up to students as partners meant opening up to students' potential to teach her about themselves as learners. This challenged the place of school assessment procedures that already provided enough data for Betty to set learning directions, but in ways that did not improve student status and influence. 
I have a sheet, 'tell me about you type thing and what you're good at and what you think you need to work on', things like that. But I mean I have to say that probably, I don't do enough of that. I'm more these are the test results, right you need work on this, this and this. (Betty)

Betty also opened up to students' potential to contribute viable reflection strategies to the trial despite her initial reservations.

It's all going to come down to what I come up with isn't it? ... they will say, 'don't make it writing', 'do this', 'don't do that'. I don't think they will be able to come up with actual ideas about what we could do, they will say what they don't want in it but then it is, yeah so that I mean student voice too, that point, but then to come up with the actual things, I don't think they will go that far. I don't know, I might be surprised. (Betty)

Betty was surprised by the reflection strategies the students contributed. Their valuable input further bolstered her commitment to working with students as partners. The class met regularly to reflect on each reflection strategy as they trialled these, before voting as a class on each strategy's efficacy to support their learning. This project space opened up pedagogical decisions to students, increased opportunities for students to talk with each other about their learning, and deepened Betty's understanding of what counted as useful, enjoyable, and time-effective reflection practice for students.

In contrast, Chicken, was comfortable from the outset with learning from her students, but noticing ongoing opportunities to do this proved more challenging. In the early stages of the home learning project the students wrote individual responses to the question, "What is effective home learning?" Chicken initially planned to analyze the students' responses herself so that she could differentiate the home learning program to address the students' preferences. Through reflective discussion in an individual planning and reflection meeting, Chicken and I noticed an opportunity for the students to analyze the responses themselves that would move the students into a more influential and active role: "You've looked through them [students' answers to home learning questions] and you've got a sense from the class discussion, is it possible for them to look through them and write some things?" (Emily). The taken-for-granted practice of teachers taking responsibility for analyzing student work was interrupted and re-framed through reflection.

The decision to offer the students the opportunity to analyze the responses was pivotal to how the home learning project evolved. The students' individual perspectives 
were re-conceptualized as data and Chicken engaged the students as partners to code the data and generate indicators of effective home learning. The students then used these indicators to redesign the class home learning program. By "letting go the reins of control" - in this case over data analysis-Chicken opened up room to learn from, and with, her students and inducted the students into deciding what counted as important pedagogy.

Opening up to student voice through familiar pedagogical strategies. The teachers adapted familiar pedagogical strategies for their class action research and coupled these with their intention to engage with students as partners. One positive effect of this was that the teachers came to view student voice as something that was within their sphere of influence.

I remember when we had our first interview and I said to you that I didn't think I did much student voice, but now that I have got on with this, I actually do, but I just don't, I never considered it that, if you know what I mean, I just thought that is what you did but then after working with you and realising that is considered student voice ... that I actually did more of it than I thought. (Betty)

Perhaps more importantly, the "students as partners" intention shifted their work with students into a new governance realm. The students helped decide what counted as important for their collective good in collaboration with the teacher. Chicken illustrated this in reflecting on student agency in the redesign of the class home learning program: "It's just more than creating activities; they're owning all of the criteria" (Chicken).

Controlling the criteria for what counted as success was a traditional teacher "job" that had been shared with students through joint inquiry.

You both initiate the inquiry, so pupil and teacher jointly initiate inquiry; pupils play an active role in decision making and plan of action in light of the data and then review the impact of their intervention. So the kids have intervened in the home work, and we've both initiated it together. (Chicken)

Lincoln utilized the school inquiry process as a vehicle for student ownership of the class program. He re-conceptualized the classroom as a film studio and the students engaged as filmmakers to inquire into filmmaking and use what they learnt to make their movie. Lincoln also vested decision-making power with the student Production Team so that they held more authority than he did as a "consultant" to the film studio. 
The Production Team accepted their decision-making authority at face value, taking on responsibility also for discipline within their team.

I had said to a couple of them 'you are in charge of organising the production crew and who is in it' and they took that to mean that they could hire and fire people they wanted. They are all giving each other warnings because of their behaviour and it is quite funny ... they are thinking that it is their power and responsibility and that they are ready and willing to abuse it. (Lincoln)

However, later in the project, gaps in the Production Team's capacity to manage the social dynamics within their group and lead the class also emerged, causing Lincoln to re-think the merits of full student ownership without stronger teacher scaffolding.

Opening up to students as partners-opening up to student feedback. Opening up to students as partners involved the teachers opening up to student feedback on their practice also: "It's good because we're often giving feedback to the kids ... and sometimes it's good for them to give you a bit of feedback" (Chicken).

However, opening up to student feedback generated discomfort for the teachers at times: "It is a little scary handing the kids the camera and saying 'tell us what you really think' ... 'don't hold back'"' (Lincoln).

Even though the teachers were engaging directly with their students as partners in the classroom, the SRG reflections, gathered as feedback on the class projects, were perceived by teachers as personal feedback on their practice. At one point, Betty expressed discomfort with the directness of SRG perspectives on the perceived value of the class research activities.

[This research] is moving towards more like a personal study on me as a teacher and I feel judged, I am starting to feel a bit judged. Before I felt that it was, in general, good teachers do this and I can reflect on it and I know personally what I do and don't do, but now I feel like I am getting hammered with what I don't do well. (Betty)

The teachers linked this discomfort with the broader school context of their work.

We have just had a [staff development] morning-quite full on, 'this is what you are doing next term for inquiry', and you are sort of being pulled every which way. Then you are trying to do really cool stuff with the kids and I am scared it is just all going to turn to $s^{* *}$ t and then I am not going to do what I, you know, what I set out to do, what I want to do. (Chicken) 
Engaging in collaborative action research with students created formal opportunities for the teachers to devote time to student perspectives as valuable professional material and to the projects as their passion. However, becoming vulnerable to student feedback on their practice, even co-constructed practice, challenged the teachers, especially within a broader professional context that they perceived as critical rather than affirming.

Opening up to student voice - complexities for teachers. Opening up to students as partners involved the teachers negotiating school expectations and policy demands contradictory to their student voice goals. They wrestled with the co-constructive expectations of engaging with students as partners and the broader accountability demands on their practice around student achievement targets.

Betty: Like we are told to do all this co-constructing thing but then we are told, we need these results and these targets met and they don't really match.

Chicken: It is really hard to get them to connect.

Betty: You don't know what's more important.

Lincoln: It is hard and you are working harder than the kids, when you are having to do that, you are having to bring them from there, to try and match that back up to now.

Chicken: And you sort of and you end up 'wooooo' [gestures overwhelm].

Betty: So you are told to do everything but they are two different ends of the spectrum.

Dominating accountability demands meant that the three teachers located their action research projects in their inquiry program, a "low-stakes" curriculum area relatively free from pedagogical prescription. They avoided high-priority curriculum areas such as literacy. Although they all agreed that student voice and literacy were compatible, prescribed pedagogies designed around student achievement targets meant that teachers were less willing to open up their literacy program to student co-construction.

We have got kids that we have to target in literacy and they have to meet those targets if not ... you panic. If I give the kids too much freedom are they going to meet the criteria? And then it comes back to you. Why aren't they, in interviews, then parents are saying, why aren't they [achieving]? What is happening? (Chicken) 
The teachers perceived that engaging with their students as partners increased their professional vulnerability to parents, colleagues, and outside agencies. For instance, with the shift in reflection on learning in Betty's class to a collaborative, oral practice, Betty worried about not having enough "proof of learning" to meet accountability demands.

I think that's why as teachers that is why we quite often revert to, okay get out your book and write this, because then it is there and you know it can be ticked off that it is done and anyone that comes in can see that is it is done, whereas anyone can say, oh well we did this paint chart and fruit machine [reflection strategy] and they have done all that and I found out this, but I could be making that up too. (Betty)

On the one hand, Betty and the students increased immediate and responsive talk and reflection about learning, themselves as learners and the impact of pedagogical strategies and messages on learning through their reflection trial. However, on the other hand, responding to student preferences created potential vulnerability with schoolwide expectations around accountability for Betty. Examples such as this foreground the limited professional autonomy the teachers perceived they had to make changes in their practice that responded to student voice around effective teaching.

There [are] times where it feels like $80 \%$ of the time, you feel like you are being told what to do and how to do it and you take $20 \%$ of the time to actually implement it ... you are being told so many different things and you just drown under it sometimes. (Lincoln)

The teachers enacted their class action research largely within the boundaries of the school-wide curriculum; they worked "in the cracks" that low-stakes curriculum areas such as inquiry learning offered them to co-construct pedagogy with their students. This may not seem unreasonable, but it did appear to limit the influence the action research projects could exert on the existing school culture.

\section{Concluding Reflections}

One of the key challenges involved in supporting teachers to learn from, and with, their students as partners was noticing when existing teaching practices no longer served the teachers' student voice goals. The ingrained and taken-for-granted nature of teacher/student roles meant that opportunities for new possibilities that would elevate student status and influence were difficult to spot in action. The need for vigilance was 
ongoing. The CAR planning and reflection meetings provided an important space in which to notice and interrupt existing assumptions as a starting point for re-framing co-constructive ways for teachers to engage with students as partners.

Limits on the teachers' autonomy to act and their potential vulnerability to established accountability demands emerged as a key consideration in the research. This has also been identified as a key tension for contemporary student voice work beyond this research (Czerniawski, 2012; Fielding, 2004). Even within a school espousing commitment to student voice, the fact that there were accountability demands on student achievement targets and requirements to demonstrate learning, meant that teachers' student voice work rendered them vulnerable to critique. School expectations on practice took precedence over the needs and preferences of individual classes, meaning that the teachers largely operated within, rather than challenging, existing boundaries on their practice to avoid potential professional censure.

One tension that continues to challenge my thinking is the need to construct spaces for teacher reflection and learning and the need to expand opportunities for students to participate as decision-making partners with teachers. The spaces for teacher reflection in this research excluded students, and this, in effect, shifted some decisions about pedagogy beyond the reach of the students. On the one hand, there were points in the research project where the perspectives of the students challenged the teachers to the point where perhaps, had they not had these student-free reflective spaces, they may have withdrawn from the research. However, it is valuable to notice where students are encouraged to participate and where the particular research design perpetuates their exclusion, especially in a project focused on opening up pedagogy to student co-construction.

Enacting student voice in classrooms is not a one-size-fits-all challenge. The teachers brought differing capacities and preconceptions about student voice, student/teacher roles, and possibilities for student influence to their student voice work, as did their students. Collaborative action research, with inbuilt spaces for teacher reflection and multiple feedback loops between participants, in the main, seemed to support teachers to open up to their students as partners in new ways that accorded students significant influence in pedagogical decisions. Sustaining these dialogic partnerships represented the enduring challenge of the research and one that provided many opportunities to reflect on how to enact ongoing student influence in a broader system where teachers' influence is at best limited. If teachers opening up to students as partners is to persist in order to elevate students' status and influence, then elevating teachers' status, influence and learning must also form an integral part of the student voice research agenda. 


\section{References}

Bragg, S. (2001). Taking a joke: Learning from the voices we don't want to hear. Forum, 43(2), 70-73.

Capello, M. (2005). Photo interviews: Eliciting data through conversations with children. Field Methods, 17(2), 170-182.

Cochran-Smith, M. (2003). Learning and unlearning: The education of teacher educators. Teaching and Teacher Education, 19, 5-28.

Collins, S. (2004). Ecology and ethics in participatory collaborative action research: An argument for the authentic participation of students in educational research. Educational Action Research, 12(3), 347-362.

Cook-Sather, A. (2002). Authorising students' perspectives: Towards trust, dialogue, and change in education. Educational Researcher, 31(4), 3-14.

Cowie, B., Otrel-Cass, K., Moreland, J., Jones, A., Cooper, B., \& Taylor, M. (2010). Teacherresearcher relationships and collaborations in research. Waikato Journal of Education, 15(2), 69-80.

Cox, S., \& Robinson-Pant, A. (2008). Power, participation and decision making in the primary classroom: Children as action researchers. Educational Action Research, 16(4), 457-468.

Curry, M. (2012). In pursuit of reciprocity: Researchers, teachers, and school reformers engaged in collaborative analysis of video records. Theory Into Practice, 51, 91-98.

Czerniawski, G. (2012). Repositioning trust: A challenge to inauthentic neoliberal uses of pupil voice. Management in Education, 26(3), 130-139.

Dwyer, S., \& Buckle, J. (2009). The space between: On being an insider-outsider in qualitative research. International Journal of Qualitative Methods, 8(1), 54-63.

Fielding, M. (2001). Beyond the rhetoric of student voice: New departures or new constraints in the transformation of 21st century schooling? Forum, 43(2), 100-110.
Fielding, M. (2004). 'New wave' student voice and the renewal of civic society. London Review of Education, 2(3), 197-217.

Flutter, J. (2007). Teacher development and pupil voice. The Curriculum Journal, 18(3), 343-354.

James, A., \& Prout, A. (Eds.). (1990). Constructing and reconstructing childhood. Basingstoke, United Kingdom: Falmer Press.

Kane, R., \& Maw, N. (2005). Making sense of learning at secondary school: Involving students to improve teaching practice. Cambridge Journal of Education, 35(3), 311-322.

Kemmis, S., \& McTaggart, R. (1989). Introduction: The nature of action research. In The action research planner (3rd ed.). Victoria, Australia: Deakin University Press.

Lincoln, Y. (1995). In search of students' voices. Theory Into Practice, 34(2), 88-93.

Little, J. (2004). 'Looking at student work' in the United States: A case of competing impulses in professional development. In C. Day \& J. Sachs (Eds.), International Handbook on the Continuing Professional Development of Teachers. England: Open University Press.

Locke, T., Alcorn, N., \& O'Neill, J. (2013). Ethical issues in collaborative action research. Educational Action Research, 21(1), 107-123.

Lodge, C. (2005). From hearing voices to engaging in dialogue: Problematising student participation in school improvement. Journal of Educational Change, 6, 125-146.

Luke, C., \& Gore, J. (1992). Introduction. In C. Luke \& J. Gore (Eds.), Feminisms and Critical Pedagogy (pp. 1-14). New York: Routledge.

Lundy, L. (2007). 'Voice' is not enough: Conceptualising Article 12 of the United Nations Convention on the Rights of the Child. British Educational Research Journal, 33(6), 927-942.

Mitchell, J. (1983). Case study and situational analysis. Sociological Review, 31(2), 187-211.

Mitra, D. (2006). Increasing student voice and moving toward youth leadership. The Prevention Researcher, 13(1), 7-10. 
Mitra, D. (2008). Balancing power in communities of practice: An examination of increasing student voice through school-based youthadult partnerships. Journal of Educational Change, 9, 221-242.

Putnam, R., \& Borko, H. (2000). What do new views of knowledge and thinking have to say about research on teacher learning? Educational Researcher, 29, 4-13.

Rudduck, J. (2007). Student voice: Student engagement, and school reform. In D. Thiessen \& A. Cook-Sather (Eds.), International handbook of student experience in elementary and secondary school (pp. 587610). Dordrecht, The Netherlands: Springer.

Smyth, J. (2006). 'When students have power': Student engagement, student voice, and the possibilities for school reform around 'dropping out' of school. International Journal of Leadership in Education, 9(4), 285-298.
Smyth, J. (2007). Toward the pedagogically engaged school: Listening to student voice as a positive response to disengagement and 'dropping out'? In D. Thiessen \& A. Cook-Sather (Eds.), International handbook of student experience in Elementary and Secondary school (pp. 635-658). Dordrecht, The Netherlands: Springer.

Taylor, C., \& Robinson, C. (2009). Student voice: Theorising power and participation. Pedagogy, Culture \& Society, 17(2), 161-175.

Thomson, P. (2011). Coming to terms with 'voice'. In G. Czerniawski \& W. Kidd (Eds.), The student voice handbook: Bridging the academic/practitioner divide (pp. 19-30). Bingley, United Kingdom: Emerald.

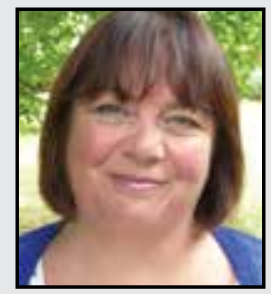

Emily Nelson is a teacher educator at the Eastern Institute of Technology, New Zealand. She currently teaches in a new innovative practice-based teacher education degree program. Emily brings experience as a primary and middle level teacher and professional development facilitator to her research work. She is motivated by student voice as socially just action. Her doctorate, completed in 2014, explored how power conditions possibilities for student and teacher action in classroom-based student voice initiatives. 